\title{
The Institutionalization of e-Democracy: Chal- lenges, Risks and Future Directions in an Indian Context
}

\section{Divya Kirti Gupta*, Ashish Kumar Biswas**}

\author{
*ORCID Nr: 0000-0002-1124-9341 \\ GITAM Hyderabad Business School, GITAM (Deemed to be University), Hyderabad Campus, Telangana, \\ INDIA divyakirti@rediffmail.com \\ ${ }^{* *}$ ORCID Nr: 0000-0001-9048-2143 ORCID iD \\ Narsee Monjee Institute of Management Studies (Deemed to be University), Tarnaka, Hyderabad, \\ Telangana, INDIA dr.ashishkumarbiswas@gmail.com
}

\begin{abstract}
This conceptual paper attempts to understand the necessity of intertwining Democracy and e-Democracy for the success of institutionalization of e-Democracy. In this respect, it proposes the "Four-Forces Framework of Democracy" and their Drivers. The paper also explores the challenges that e-Democracy may face in its growth and evolution, highlights the risks involved in ignoring the challenges, and suggests the future direction. In the present scenario, there is a considerable push for Information and Communication Technology (ICT). The paper discusses whether this will lead to the strengthening of people's voice and empowerment of the individual and collective aspirations. Societies in their evolution develop cultural contexts, social and ethnic values. It is a challenge for any e-Democracy to integrate them into its mechanisms. In the Indian context, it is essential to develop foresight on how e-Democracy gears-up to also address various contradictions and conflicts, which are possible due to the digital-divide, multitude of people's aspirations, socio-cultural diversity, space for democratic thinking, etc. Keeping many aspects of Democracy and governance into consideration, the paper focuses on how ICT and e-Democracy will honour people's aspirations in the coming years, to keep the public, individual, and society, vibrant and democratically functioning.
\end{abstract}

Keywords: e-Democracy, ICT, Democracy, e-Government, Digital Democracy, Internet Democracy, e-Participation

\section{Introduction}

Emphasis on e-Democracy is growing. The current literature shows that it is also referred to as Digital Democracy and Internet Democracy (Manazir \& Govind, 2019; Richardson \& Emerson, 2018) and is being showcased as a setup for effective and efficient governance of the masses. Information 
and Communication Technology (ICT) is one major force driving the interest and shift towards eDemocracy (Amoretti, 2007). Since 2009, Information and Telecommunications Union (ITU) is publishing ICT Development Index (IDI) with ICT access, ICT use, and ICT skills as the indicators.

So far, the societies and the countries have evolved and adopted Democracy as a system that satisfactorily gives expression to their cultural, social, and ethnic backgrounds and aspirations. Bozdag and Van den Hoven (2015) and Richardson and Emerson (2018) discuss the aspects, focus areas, purposes, and frameworks of democracies world over. Their work helps understand that the process of e-Democratization is intricate, complex, and requires the involvement of specialists from multiple domains and specializations.

Since e-Democracy is in initial phase in India, the paper proposes the need for 'Institutionalization of e-Democracy', where the norms, functioning and goals, are set in the initial phases. This is also required for the reason that e-Democracy may not be understood as a system that merely uses ICT in the Democracy. The paper proposes a framework, which is generic in nature, but holds special reference to Indian context as most of the discussion centres around it.

Towards this, the paper explores the current understanding of the e-Democracy and discusses how democracies, across the world, are embracing and integrating ICT tools and platforms in their shift towards e-Democracy. It also elaborates on the challenges involved in this transition and the risks involved in overlooking some of those challenges, in general, and especially with respect to India. It suggests the framework for future work on e-Democracy in the form of "Institutionalization of e-Democracy" which is applicable for democracies in general and to India, in particular.

\section{Literature Review: Democracy and e-Democracy}

What is noticeable is that there are vast variations in people's appreciation of the concept of Democracy. It is a challenge for many to understand the 'Intent' of Democracy and develop a mindset for a democratic system of governance. In such a scenario, e-Democracy is coming up in a big way. The transition towards e-Democracy across the globe is being seen as a step forward in the direction of democratic governance. It is being studied and researched with great interest by scholars, political systems, and people.

Democracy refers very roughly to a method of group decision making, characterized by equality among the participants as an important stage of the collective decision making (Christiano, 2006 as cited by Bozdag \& Van den Hoven, 2015). Societies and nations have evolved and adopted Democracy as a system that satisfactorily gives expression to their cultural, social, and ethnic backgrounds and aspirations.

Today scholars and practitioners use terms like e-Government, e-Democracy, e-Participation, and e-Engagement. The motivations for e-Government are many. Speed, wider reach, increase in transparency and accountability of the office bearers, cost efficiency, and effective and convenient ways of delivering services to the citizens are a few reasons. This is largely facilitated by advancements in ICT, and availability of the technology for e-Government work (Karna \& Gupta, 2011). But, the technology and the mechanisms are evolving across the world. UN e-Government Survey (2016) cites 
many examples from countries world over, showing ICT to be a significant enabler. Its integration in government departments has improved their functioning, with the public services getting rendered with greater efficiency and effectiveness.

But, e-Democracy goes beyond the idea of e-Government. Lee, Chang and Berry (2011) treat eGovernment and e-Democracy as two distinct concepts and explore the antecedents of both. According to them, e-Government uses ICT to provide citizens with information on public services. And the less pervasive e-Democracy, offers greater electronic community access to the political processes and policy choices. They concluded that e-Government was a more mature policy area than e-Democracy, and that e-Democracy needs to be studied further.

Garson, who argues that e-Democracy is an umbrella term covering many democratic activities carried out through electronic means, broadly defines e-Democracy as the use of ICT by the government to improve the efficiency, equity, and quality of democratic participation (Garson, 2006 as quoted in Lee, Chang \& Berry, 2011). The major applications of e-Democracy include mechanisms to inform, consult, and broadly engage citizens through the use of ICT in the political process, and these mechanisms are usually called e-Participation or e-engagement (Lee, Chang \& Berry, 2011). Van der Graft and Svensson (2006), in their study on the development of e-Democracy in Dutch municipalities, find technology playing a pivotal role in the process.

Though there are studies on e-participation, e.g., Medaglia (2007) focused on the ICT's use to enable citizen participation by Italian local government and Boyd (2008) studied differences in eDemocracy parties' e-Participation systems, but nothing has been proved concretely. The models of e-Democracy are yet to emerge.

Medaglia (2012) studied 122 research articles, ranging from April 2006 to March 2011, within the categories of e-Participation actors, activities, contextual factors, effects, evaluation, and methods. He identifies the need to move beyond a technological perspective, encouraging the ongoing shift of research focus from government to citizens and other stakeholders. He emphasizes the need to make e-Participation research methods more participatory.

It is still difficult to enumerate the benefits accrued from the shift towards e-Democracy because there are many engagement and participation issues apart from ICT. Federici, Braccini and Sæbø (2015), while studying the use of ICT in involving citizens in political decision-making, observe that ICT is becoming an ever more popular way to involve citizens in political decision-making. But, despite their recently increasing number, few e-Participation initiatives have achieved their intended aims. And they opine that the internal processes, challenges, and opportunities of using ICT to engage citizens in politics deserve further examination.

Richardson and Emerson (2018) see e-Democracy as a medium with profound ability to extend community engagement, expand suffrage and citizen agency, create real-time decision making, rapidly aggregate opinion data, and pave the way for a shift from representative to more direct forms of Democracy in the times when there is a crisis of faith in Democracy and democratic institution's capacity to address society's social and environmental challenges. 
E-Democracy and e-Government are indeed the future of any country. Still, it is essential to understand if they will have the capacity to uphold the values of Democracy and would provide democratic governance to society. For example, Mohiddin (2002), in the context of Africa, observes that critical questions revolve around conceptions, implementation, maintenance, affordability, and evaluation of the possible consequences of implementing e-Democracy on the structures and values of African societies, economy, and politics; Will e-Democracy strengthen or weaken the African sense of community, cohesion, and solidarity? Paganelli and Pecchi (2013) are of the view that eParticipation involves the use of ICT for facilitating the two-way communication between governments and citizens. And, designing e-Participation activities is a complex task. They highlight the challenges in this direction - the need for interdisciplinary expertise and knowledge (e.g., in political, sociological, usability, and technological domains), and the lack of widely accepted models and technological standards.

With this understanding of Democracy and e-Democracy and their significant intertwining, the next section details some of the challenges that e-Democracy faces in its evolution.

\section{Challenges in the Growth and Evolution of e-Democracy}

From the second half of the twentieth century for many countries in the modern world, Democracy came as a new form of governance. The traditional forms of governance in those countries were very different from their current democratic setups, especially in the countries from Asia and Africa. It is also a fact that today democracies, the world over, are in different phases of evolution, and this variation is more evident in developing countries. More so, the road to e-Democracy is yet to be charted and is evolving each day as countries experiment, implement and learn from their policies and initiatives.

After arriving at a clear understanding of e-Democracy in the previous section, it is important to discuss the challenges that the democracies may face while they transition to e-Democracy. It will help in better planning and implementation at various stages. This section focuses on the universal challenges involved in this process, for the Democracies, and also the ones specific to India, as understood by the authors.

The first challenge for a democracy is to ensure that the basic framework of Democracy remains intact in the transition to e-Democracy and the power continues to rest with the citizens. It is the planners' responsibility to ensure that the systems and mechanisms of e-Democracy continue to give power to the people, instead of the power getting concentrated in the hands of a few, or getting confined to those who have access to e-Democracy's plan and design. In this direction, Richardson and Emerson (2018) outline two challenges for the USA. One is validation, which is not just about developing hack-proof voting machines but ensuring the presence of all the system-checks provided by the current system of voting, and the second is about delegation, indicating a shift to 'liquid democracy' from the contemporary representative Democracy because of decreased faith in the representatives. 
The second challenge, which is felt equally by politicians, policymakers, and ICT professionals, is ICT's capacity to define a political system instead of getting defined by it. Today ICT is acting as a major driver in the process. Though Richardson and Emerson (2018) look at the defining role of ICT in this transition in the form of ICT leading to multichannel communication and news ways of aggregating opinions to liberate e-Democracy from majoritarianism, there is concern over increasing hold of ICT on the entire process of transition.

Researchers are raising this concern in different ways. Bozdag and Van den Hoven (2015) mention the need to design alternate algorithm and digital tools to combat 'filter bubbles' that get created by the algorithms used by search engines, social networking platforms, and other online intermediaries that decrease the information diversity and are detrimental to the cause of Democracy. In their work on 'filter bubbles', they discuss the four models of Democracy - Liberal Democracy, Deliberative Democracy, Republicanism, and Contestatory Democracy, and Agnostic/inclusive political communication democracy, along with the norms associated with each form and the software designs to combat 'filter bubbles'. They argue that Democracy itself is a contested concept with a variety of norms. In their opinion, the designers of diversity enhancing tools must be exposed to the diverse conceptions of Democracy. This part is just a miniscule part of the total complexity of the transition.

Bozdag and Van den Hoven (2015) cite Cyberbalkanization as another challenge, where the idea of segregation of the Internet into small political groups with similar perspectives happens to such an extent that people show a narrow-minded approach to those with contradictory views. This phenomenon is detrimental to the spirit of Democracy. Though ICT provides ease of interaction, users must be cautious to understand that the platforms and tools have inherent biases and that may affect their decisions.

The third challenge is the accessibility to technology and difficulty in coping with digital transformation speed, which further adds to the inherent complexity of the transition. Growing DigitalDivide, though the domain of ICT is making exponential growth, is a challenge. Access, people's socio-economic status, and digital skills are some of the reasons for this divide (Ebbers, van Deursan \& Jansen, 2016). Among many other challenges Manazir and Govind (2019) discuss digital-divide and shutting-down of the Internet as another problem. Richardson and Emerson (2018) mention that though e-Democracy's promise is universal, for real-time participation of people in the political process, there would still be a need to address issues like - 'right of participation' and 'equality of access.'

Connected to this is the next challenge. The size and growth of an economy impacts the availability and accessibility to the resources. They influence the policy making and implementation. Hence the fourth challenge, is to understand how the transition to e-Democracy would get impacted by the complexities and size of the economy before the transition process is initiated. And it is equally important to understand the impact of this transition on society?

Democracies worldwide have social, cultural, and ethnic diversity, which are intangible and have emotive dimensions. Democracy, by its nature, gives space for the existence of diversities. The fifth challenge for e-Democracy is how it integrates social, cultural, and ethnic diversity in its folds? What if such diversity doesn't find appreciation? What if they are ignored? Or, what if they are demolished 
and ruled over, either due to technology's failure to provide solutions for their integration or the inherent difficulty in deciphering the multi-layered nature of diversity leading to simplistic solutions?

The sixth challenge for e-Democracy is to be able to uphold the trust of people and collectively grow into an e-Democracy. High-speed growth of ICTs and leaders' eagerness to integrate ICTs in governance are at the base of this challenge for three reasons - first, that Democracy has given sufficient space and time for people to grow and evolve together. It would be a challenge for e-Democracy to provide similar space and time to people, where they would collectively develop into better e-Democracy; second, the high-speed growth of ICT may leave little time and opportunity for stocktaking, thereby bringing flaws into the e-democracy; and thirdly, the nature and skills required for e-communication and e-engagement are different from the traditional modes of communications adopted for people's engagement. If not addressed, these may affect the trust of people or stakeholders in e-Democracy.

Touching upon this challenge is the work of Aziz and Hasna (2020) in the context of development of e-Democracy policy in Indonesia. Aziz and Hasna (2020) identify creation of new public spaces for political interaction and deliberation. They suggest that e-Democracy policy should provide for multi-directional interactive communication channels to connect citizens, representatives and government for meaningful interactions. They recommend that sufficient high-quality online information be ensured so that citizens can consider policy options based on trusted knowledge, as well as their own subjective experiences; and the processes should reflect the reality of geography and social structure in the online environment, to provide equal access to the democratic process for all fields and all communities.

Coming to India's context, according to the Indian Census (n.d.) last conducted in year 2011, India has a population of 1.22 billion. The challenges discussed above are applicable to India also. But the position of India acquires uniqueness when the population is looked at in light of aspects like: India's federal structure, its political system, presence of regional priorities, its multi-lingual and multi-religious demography, socio-cultural diversity, economic gaps and disparities, state of ICT infrastructure, access to ICT, literacy rates, access to education, current engagement and involvement of people in political discourse and collective decision making etc. A more nuanced and thoughtful understanding on part part of policymakers and technologists would pave the way for a complete and holistic transition to e-Democracy in India.

Singh (2010) raises the concern of a digital-divide, but concludes his work on a positive note, suggesting that it may narrow in coming years, though it will be quite challenging for the central and state governments. Moreover, the current COVID-19 pandemic has put pressure on the Governments world-over and has exposed the gaps and the fault-lines in the governance mechanisms and growth models (Gupta \& Biswas, 2020). India is gearing up to bridge this gap that requires humongous efforts due to the unprecedented demands of the current pandemic (Beniwal, 17 December, 2020).

The 'Digital India' initiative of the Government of India (www.digitalindia.gov.in), launched in 2015, is a significant step in the direction of narrowing the 'Digital-Divide'. The vision of the 
programme is to transform India into a digitally empowered society and knowledge economy. The programme envisions three areas of digital India: Digital infrastructure as a core utility to every citizen; Governance \& services on demand; and Digital empowerment of citizens. Concrete schemes have started in each area, thereby improving the delivery of services in a transparent and effective way.

The Preamble to the Constitution of India declares India to be a 'sovereign, socialist, secular, democratic republic, and to secure to all its citizens justice, equality, liberty, and fraternity' (The Constitution of India, 1977). It is a country of diverse identities with diverse viewpoints. The current setup of Democracy provides space for the expression of those identities and viewpoints. How would e-Democracy accommodate them and then address them, allowing the hues \& shades of opinions supported by Democracy otherwise? It will be a challenge for e-Democracy that instead of becoming binary and majority-driven, as mentioned by Richardson \& Emerson (2018), how will it remain analog, allowing the integration of the minority \& marginalized's opinions? If appropriate mechanisms are not incorporated into the transition, it may lead to intolerance, reactions, and retribution.

In India, behavioral and linguistic dimensions have explicit mention and place in the democratic set-up. Though these issues are very complex, they still get addressed. There is a place for adjustment and alignment of these issues in a democratic setup. But, the current 'macro' nature of e-Democracy poses a challenge. How will e-Democracy address the crucial 'meso' and 'micro' issues in the coming times? The creation of such a space is a challenge for e-Democracy setups, which will otherwise shrink the democratic space, leading to a change in the DNA of the Democracy.

Increased use of ICT tools in e-Democracy require the collection of the citizens' data, which is accessible to multiple agencies. Hence, the challenge for e-Democracy in India is to ensure no infringement on privacy and no compromise with the security of the individuals, groups, and society. This concern has affected people and even the progress of the projects on Aadhaar Card (Shukla, September 27, 2018 and Jain, 2019) and the National Register of Citizens (NRC) in India (Singh, June $15,2020)$.

As part of increasing investment in ICT in the last two decades, and programmes like 'Digital India', there are many initiatives that now involve intensive use of ICT to improve the services. Alathur, Ilavarasan and Gupta (2011) cite some of those as e-Governance initiatives leading to eParticipation platforms like: the introduction of electronic voting machines (EVMs); the Central Vigilance Commission's Vigeye project in 2010 setup to empower the citizens to fight against corruption; various e-petitioning systems including the public redress mechanisms of Government of India, like: e-Abhijoga (of Odisha), Prajavani (of Andhra Pradesh), e-Samadhan of Rajasthan and the Sutharyakeralam of Kerala. Iyer (2014) mentions the initiatives like voter-helplines, real-time monitoring of voter turn-out, transparency in sharing data from counting centers etc. There is an immense shift, but a lot of work still needs to be done in joining these initiatives together. When looked at in the light of the discussion on e-Democracy and e-Government, most of the initiatives fall into the category of e-Government and e-Governance. The area of e-Democracy and e-Participation is yet to get addressed. 
Another foreseen challenge for e-Democracy in India is how it would nurture the democratic thinking and mind-set? How the idea of 3D - Discussion, Dialogue, and Discourse (Sharma, 1996) would continue to find existence in e-Democracy. In his work Sen (2005) emphasizes that 'public reasoning' deeply influences Indian politics, and is particularly relevant to the development of Democracy in India and the emergence of its secular priorities. He categorically emphasizes that when India chose a resolutely democratic constitution, it also drew on its tradition of public reasoning and argumentative heterodoxy. How Noble Laureate Amartya Sen's 'Argumentative Indian' (Sen, 2005) will find a place in e-Democracy would be another challenge?

The current understanding of Democracy in India is that the foundation of Indian Democracy stands on four pillars - Legislature, Executive, Judiciary, and the last, added in the recent past is the Press. So far, the four organs have functioned in harmony because they had time and space to do so. They have served towards the freedom enshrined in the democratic values and ideals set for the individuals, public, and society. The use of ICT in governance has brought in the idea that Democracy can be conveniently and effectively transformed into e-Democracy. But, what if any of the pillars of Democracy, say Legislature and Executive, decide to ignore the Judiciary and the Press and vice-versa! How do they get addressed, and what happens to those scenarios in e-Democracy? Addressing this issue in its depth and expanse would be a tedious exercise in this transition.

Summarizing, the challenges mentioned above, in a global and in an Indian context, are not exhaustive and may vary according to the nature and structure of Democracy in different countries. What is essential is that the countries develop such a list of challenges while undertaking the journey towards e-Democracy. This will ensure a smooth transition, and healthy and holistic functioning of e-Democracy. It may be inferred that e-Government, e-Participation, e-Democracy currently address the 'efficiency' dimension of a democratic setup; It is necessary that they also address the 'values' and 'intent' dimension of a Democracy.

Amoretti (2007) captures the efforts that have to be made for e-Democracy with ICT as a facilitator:

.....Consequently, rethinking the interaction between the state and the citizen towards a partnership, which actively promotes participatory decision-making is needed. This involves redefining institutions, processes and mechanisms whereby information is supplied and information is demanded. Governments need to formulate a national strategy based on the holistic concept of e-inclusion, whose goal is access for all: ICTs considered not just another factor of production, but rather a unique opportunity for achieving higher standards of living and greater economic and social empowerment of the millions of citizens around the world.....(Amoretti, 2007, p.10)

Based on the discussions on challenges and the spirit with which e-Democracy has to be given direction by countries worldwide, the next section proposes the concept and broad framework of the 'Institutionalization of e-Democracy' with an aim to channelize the evolution of e-Democracy in a country. 


\section{The institutionalization of e-Democracy}

As defined by Cremer (cited in Keizer, 2008), institutions refer to man-made rules that govern human behaviour and the dictionary meaning of 'Institutionalization' is the action of establishing something as a convention or norm in an organization or culture. Keizer (2008) opines that though the meaning of institution varies across disciplines, but their existence matters. Mohr and White (2008) write that institutions are linkage mechanisms that bridge across three kinds of social divides - they link micro systems of social interaction to meso (and macro) levels of organization, they connect the symbolic with the material, and the agentic with the structural.

In the context of e-Democracy the 'Institutionalization of e-Democracy' means the actions taken to ensure that e-Democracy has the elements of Democracy in it, which gives credible and reliable information to its citizens, gives them a platform to discuss and dialogue, and draw input from four forces that exist in a society viz: market, state, people and 'Self', as outlined by Sharma (2018).

Towards this, "Four-Forces Framework of Democracy" is proposed in this paper which represents four distinct forces operating in a democracy. This framework is an extension of the "Four Forces Model of Holistic Globalization" (Sharma, 2018), where Sharma identifies four forces that operate in any society viz. 'Force of Market', 'Force of State', 'Force of People' and 'Force of Self'. 'Force of Market' is increasingly represented by corporates; 'Force of State' is represented by political systems or governments; 'Force of People' is represented by social entrepreneurship, social enterprise, people movements etc; and 'Force of Self' is represented by human consciousness or spirituality. He suggests that a proper balance between these four forces is needed to create harmony in society.

Fig. 1 represents The "Four-Forces Framework of Democracy" with each force's key drivers. On the horizontal axis is the 'Force of State,' driven by the ideology/-ism of the ruling party, and on the right is the 'Force of Market,' driven by the idea of profits/efficiency. On the vertical axis, it's the 'Force of People,' driven by the idea of Sustenance/Identity and 'Force of 'Self,' driven by the idea of Higher aspirations/Values of human beings. 
Fig. 1: "Four-Forces Framework of Democracy" and their Drivers

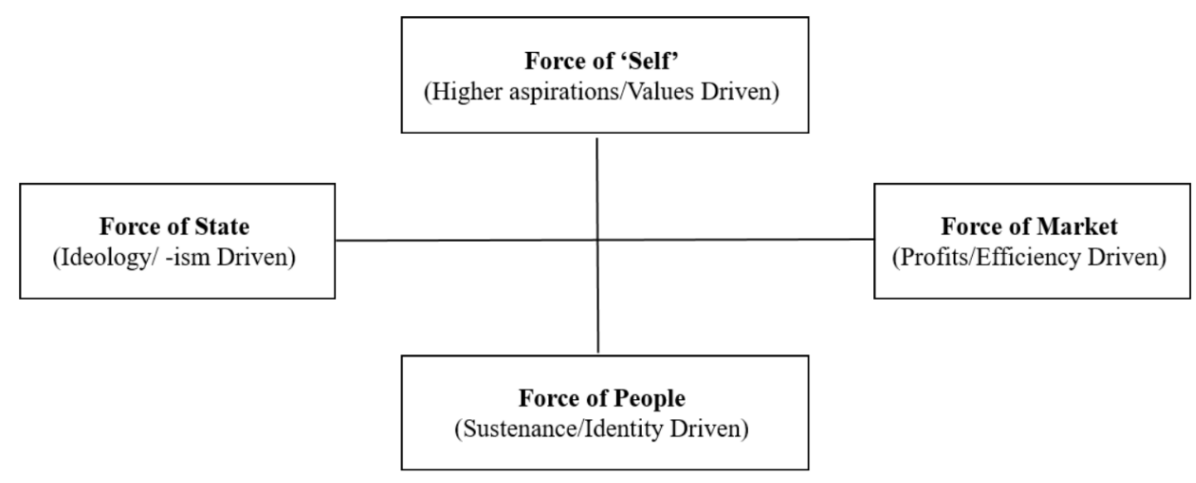

In a democracy, there is always a likelihood of one force gaining more weight than the other, leading to a disbalance or disruption in the harmony of the democratic setup. The situation in a Democracy becomes more difficult and complex when one force colludes with the other force, leading to suppression of other forces. For example, when the 'Force of State' colludes with the 'Force of Market,' then people tend to get an unfair deal, their freedom and privacy get hurt, and the existence of the 'Higher-Self' of a human-being loses an opportunity to express itself. A pertinent point in the institutionalization of e-Democracy is how these four forces dynamically interact with each other for effective functioning and harmony in society?

It is also time to analyze the drive pushing people towards e-Democracy to understand what happens to 'individual' existence in this networked Democracy and governance. Moreover, in the globalized world today, the influence of one type of Democracy over the other is evident and needs consideration in this process of e-Democracy.

Fig. 2 is the pictorial representation of the institutionalization of e-Democracy and the possible process to implement it. The process involves three broad steps. The figure's left side represents the usual course adopted by a country to conceptualize a democratic setup and its governance mechanisms. The figure's right side represents the steps to be followed in conceptualizing e-Democracy, its systems, policies, and practices.

The integration of democratic values and democratic intent into the DNA of e-Democracy is a crucial part of institutionalization that enables their manifestation in the second and third steps of e-democracy. In any country, this would require active engagement and involvement of the Governments, policymakers, technologists, people, etc. 
Fig. 2: The institutionalization of e-Democracy

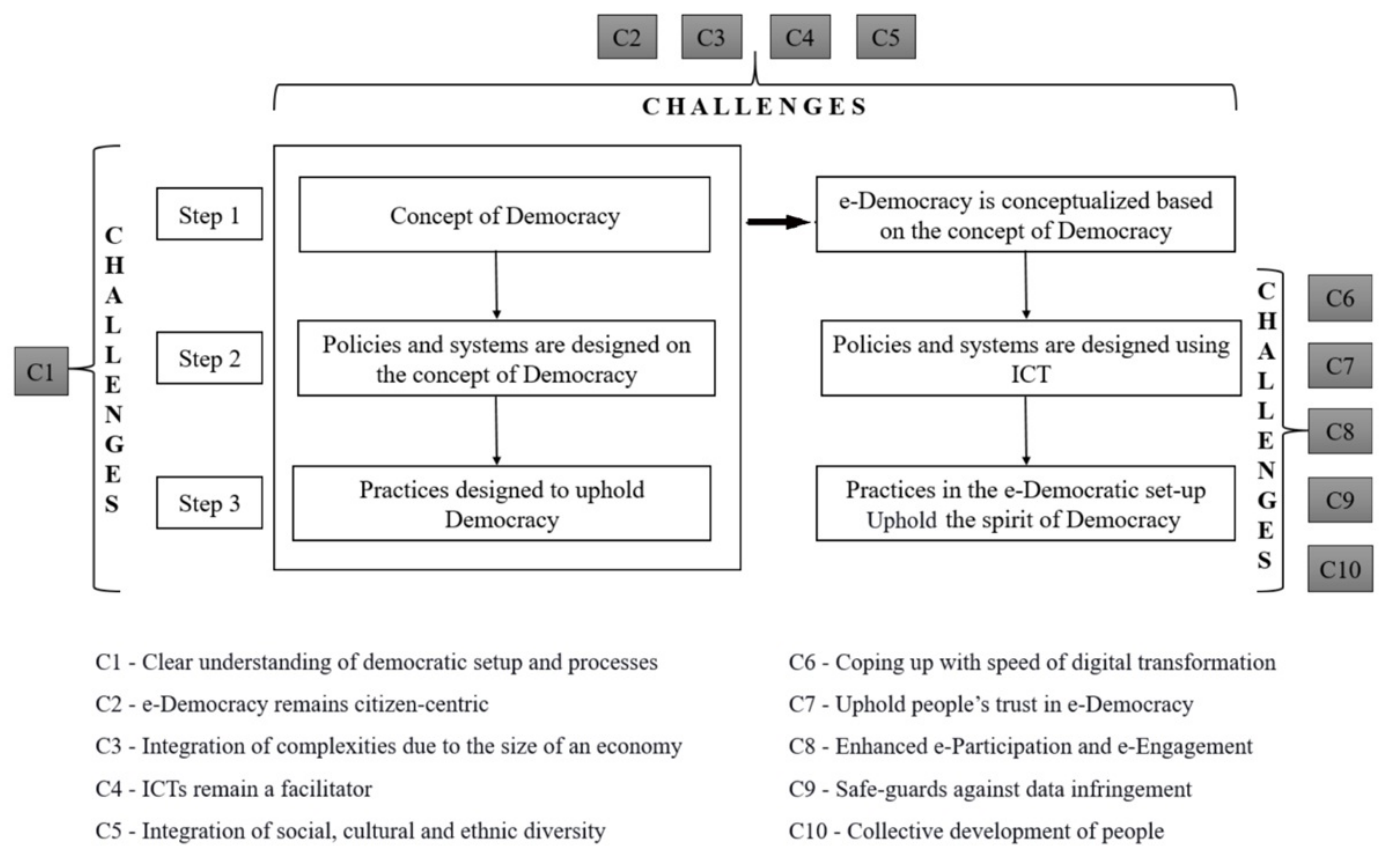

This framework will help address the challenges detailed in the previous section because it starts with the discussion on the shape, structure, and requirements of e-Democracy before designing various systems and processes. In the absence of the institutionalization of e-Democracy, there are chances that ICT may advance with a speed and mechanisms that overtake/ sideline the democratic evolution of individuals, the public, and society.

After this discussion on the institutionalization of e-democracy, the next section details the risks involved if the challenges mentioned in the previous section are ignored or not addressed by the planners.

\section{The risks Involved in Ignoring the Challenges}

This section highlights the risks that may arise, when the challenges in the growth and evolution of e-Democracy are not addressed. The risks analysed in this section are of two types: those that apply to e-Democracy in general, including India, and then those that may be considered specific to India.

This first risk arises when ICT is not given the role of a facilitator and is allowed to drive the process of institutionalization. In such a scenario, there are chances of democratic governments changing to authoritarian governments with the tools of ICT. Denyer (2016) proposes to imagine a world where an authoritarian government monitors everything you do, amasses massive amounts of data on almost every interaction you make, and awards you a single score that measures how "trustworthy" you are. 
What happens if a Government decides to control all aspects of an individual's life and uses its citizens' digital data as a social control mechanism? There is a chance that access to data and information may motivate regimes to become authoritarian. Abusleme (2020) examines the theory that politicians do not have many incentives to make the policy process more democratic, and that these political dynamics may be embedded into the enactment of technology. So, what will happen in a scenario, where democratic setups and democratic values get replaced by authoritarian leaders and authoritarian setups, camouflaging themselves as democratic-setups? In light of such possibilities, planners and policymakers must consider building the checks and balances into the e-Democracy process and systems in the initial phases. Though China is not a democracy, but it's 'Social Credit System', where it wants to give every citizen a score based on behaviors such as spending habits, turnstile violations, and filial piety, which can blacklist citizens from loans, jobs, air travel (Chin \& Wong, 2016) has fuelled scepticism around the use of ICT (Liang et al, 2018) and has led scholars to envision scenarios, should democratic countries continue to do without stricter data use policies in place (Wong \& Dobson, 2019).

The second risk for e-Democracy is a possible attempt to silence the differences of opinions. It is envisaged that the increased use of ICT in governance will increase e-participation, leading to increased expression of people's voices. But there is a flip side to it also. And this is one area that requires intervention. One can see the increased misuse of e-participation in terms of "Trolling" or "Troll." Bishop (2014) elaborates on how trolls show a darker, sinister and transgressive side of cyberspace in the form of abuse and vitriol. The examples are plenty, the world over, where leading personalities, parties, journalists, film stars, etc. have been trolled in an organized/anonymous way. The generally observed trend is that trolls are used to silence alternate voices, opinions, interests, etc.

The third risk is the marginalization of the underprivileged in any e-Democratic setup. Raising the concern that Mohiddin (2002) asks; will e-democracy further weaken what little influence the poor have over their ruler, with impersonal cyber interface replacing the face-to-face human relations? Here, people may get left out because the system may not have the strength to include them. The risk is that they will never benefit from e-Democracy and e-Governance.

In spite of all the success of e-Government initiatives, the last risk for e-Democracy is that its systems and processes may become insensitive to the troubles, pains, and sufferings of the people in the haste of transformation from Democracy to e-Democracy. Such haste would subvert the human dimension of Democracy. In this context, the decision of demonetization in India on November 8, 2016 may be studied, where the intent of the government was to root out black money and make people switch to a digital economy and the trouble it posed for the masses.

"Indians should not be forced to go cashless despite the government's laudable efforts to root out black money", this was the take of Muhammad Yunus, the founder of the Grameen Bank of Bangladesh awarded the Nobel Peace Prize for pioneering the concept of microcredit and microfinance (Bagla, January 3, 2017). Speaking to NDTV on the sidelines of 104th Indian Science Congress, regarding the Government's notes ban and the efforts to push for cashless transactions to bring transparency into the system, Mr. Yunus lauded the government's war on black money but 
emphasized that people should be allowed to embrace the digital economy at their own pace (Bagla, January 3, 2017).

For the institutionalization of e-Democracy, it is pertinent that the Governments, planners, practitioners, and other stakeholders in society address the challenges and the risks leading to enhanced faith in, and participation of the masses in, the e-democratic processes and decision-making.

\section{Conclusion and Directions for Future}

'The institutionalization of e-Democracy' is about making conscious efforts to align e-Democracy with the spirit of Democracy and the democratic process in a country. In the Indian context, it would mean integrating the nuances of parliamentary Democracy into the systems and processes being designed for e-Democracy, and not leaving the process of transition to ICT and e-Government.

Based on the discussions in the paper, it can be contemplated for India and other democracies today, that ICT must play a supportive role in societies' evolution and not act as a driving force shaping the democratic setups based on available technology, algorithms and data. This paper has implications for future research in this area, required for elimination of possible contradictions, confusion, and conflicts among various stakeholders of e-democracy in terms of their participation, inclusion and representation.

Also, the purpose of Democracy is to fulfil the aspirations of a larger number of people in a sociopolitical setup. Future researches and scholarly discussions may investigate and understand how eDemocracy complements Democracy in a country. In order to move towards this it would be essential to ascertain who the custodians of e-Democracy would be? Will they be a set of people who would hold power over ICT, or would they be the citizens? When the systems embrace ICT and move towards e-Democracy, the discussion on this question will ascertain citizen rights and their participation in the democratic processes.

The paper also highlights a concern that would need attention in coming times. With the increasing levels of efficiency and effectiveness, which would be achieved through e-Democratic setups, governments will have to look for solutions for the time and energy-surplus that will get created at individual levels in different countries.

The discussions in the paper also draw attention to the speed of transition from Democracy to eDemocracy in any country. It proposes the need for an evolutionary approach so that there's sufficient time for people to become aware of the changes brought in by e-Democracy and renewed expectations that come along. Any other approach will be disruptive to the existing systems leaving a void for the people. This aspect also involves building 'the trust of people in the transition process.' To enable the strengthening of e-Democracy with a human angle, there is an enhanced need to search for mechanisms that uphold people's trust in this process of transition. It is pertinent to design mechanisms that allow people to evolve together, making spaces for alternate voices, opinions, and traditions. In India's context, seeing the diversity of cultures, political thoughts, and people's socioeconomic status, this area needs utmost attention as the country transitions from Democracy to eDemocracy. 
The paper has certain limitations. First, quantitative data may be required to support the issues raised - the paper examines the areas currently being focused on in e-Democracy research and based on them draws a conclusion on issues and risks. Second, the journey of each democracy transitioning to e-Democracy may be different - the paper has a twin focus and highlights the challenges for eDemocracy in general and also those that may require more attention with reference to India. But, despite these limitations, the paper not only sheds light on the current work being done on e-Democracy, it also brings together the arguments and concerns from different disciplines, giving this paper a multi-disciplinary construct, which is required for an holistic understanding of e-Democracy and its progression in any society. There is a broad framework for the 'Institutionalization of e-Democracy' suggested in the paper, which would be used in future work to understand the transition of a Democracy to an e-Democracy.

\section{References}

2011 Indian Census (n.d.). Retrieved from https://censusindia.gov.in/2011-common/censusdata2011.html

Abusleme, C. (2020). Cracking the Political Code: The Case of e-Participation in Colombia. JeDEM 12 (2): 192-215, 2020 ISSN 2075-9517 Article DOI: 10.29379/jedem.v12i2.605

Alathur, S., Ilavarasan, V., \& Gupta, M.P. (2011). Citizen Empowerment and Participation in e-Democracy: Indian context. ACM International Conference Proceeding Series. 11-19. 10.1145/2072069.2072072. Retrieved from https://www.researchgate.net/publication/221547558_Citizen_empowerment_and_participation_in_e-democracy_Indian_context

Amoretti, F. (2007). ICTs Policies: E-Democracy and E-Government for Political Development. Retrieved from https:/ / repository.upenn.edu/cgi/viewcontent.cgi?article=1007\&context=ictafrica

Aziz, M. S., \& Hasna, S. (21 December, 2020). The Problem of e-Democracy and its Impact on Political Participation in Indonesia. Published in the Proceedings of 6th International Conference on Social and Political Sciences (ICOSAPS 2020). DOI: https:// doi.org/10.2991/assehr.k.201219.071. Retrieved from https://www.atlantis-press.com/proceedings/icosaps-20/125949686

Bagla, P. (January 3, 2017). Don't Force Indians To Go Cashless': Nobel Laureate's Advice For PM Modi. Retrieved from http://www.ndtv.com/india-news/dont-force-indians-to-go-cashless-nobel-laureatesadvice-for-pm-modi-1644645

Bishop, J. (2014). Representations of 'Trolls' in Mass Media Communication: A Review of Media-Texts and Moral Panics Relating to 'Internet Trolling'. International Journal of Web Based Communities. 10. 7-24. 10.1504/IJWBC.2014.058384

Boyd, O. P. (2008). Difference in eDemocracy Parties' eParticipation Systems. Information Polity: The International Journal of Government \& Democracy in the Information Age. Vol. 13, ISSUE 3/4, p167-188.

Bozdag, E., \& Van den Hoven, M. J (2015). Breaking the Filter Bubble: Democracy and Design. Ethics and Information Technology, 17(4), 249-265. Retrieved from https://repository.tudelft.nl/islandora/object/uuid\%3Ae24751ba-b94b-4856-b4a9-2f5f4f25ff14 
Chin, J., \& Wong, G. (November 28, 2016). China's New Tool for Social Control: A Credit Rating for Everything. Retrieved from http://www.wsj.com/articles/chinas-new-tool-for-social-control-a-credit-ratingfor-everything-1480351590

Denyer, S. (October 22, 2016). China Wants to Give All of Its Citizens a Score - and Their Rating Could Affect Every Area of Their Lives. Retrieved from http:/ /www.independent.co.uk/news/world/asia/china-surveillance-big-data-score-censorship-a7375221.html

Ebbers, W., van Deursan, A. J. A. M., \& Jansen, M. G. M. (2016). Impact of the Digital Divide on e-Government: Expanding from Channel Choice to Channel Usage. Government Information Quarterly. Vol. 33, Issue 4, p685-692.

Federici, T., Braccini, A. M., \& Sæbø, Ø. (2015). ‘Gentlemen, All Aboard!' ICT and Party Politics: Reflections from a Mass-eParticipation Experience. Government Information Quarterly. Vol. 32, Issue 3, p287-298

Gupta, D. K., \& Biswas, A. K. (June 02, 2020). Corona Redefining Business and Management Education. Hans India. Retrieved from https://www.thehansindia.com/hans/opinion/news-analysis/corona-redefining-business-and-management-education-625788

Iyer, L. S. (2014). Opportunities and Challenges in implementing e-Democracy in India. The International Journal Research Publication's Research Journal of Science \& IT Management, p9-25. Retrieved from https://www.researchgate.net/publication/301754829_Opportunities_Challenges_in_Implementing_e-Democracy_in_India

Jain, M. (May 19, 2019). The Aadhaar Card: Cybersecurity Issues with India's Biometric Experiment. Retrieved from https://jsis.washington.edu/news/the-aadhaar-card-cybersecurity-issues-with-indiasbiometric-experiment/

Karna, S. R., \& Gupta, D. K. (2011) Fostering e-Government as State Social Responsibility (SSR): Case Study of an Australian City Council. Journal of eDemocracy \& Open Government, 4(2): 318-337, ISSN 20759517. http://www.jedem.org/index.php/jedem/article/view/145

Lee, C., Chang, K., \& Berry, F. S. (2011). Testing the Development and Diffusion of E-Government and E-Democracy: A Global Perspective [Abstract]. Public Administration Review, May/June, pp 444-454. Retrieved from https://onlinelibrary.wiley.com/doi/abs/10.1111/j.1540-6210.2011.02228.x

Liang, F., Das, V., Kostyuk, N., \& Hussain, M. M. (2018). Constructing a Data Driven Society: China's Social Credit System as a State Surveillance Infrastructure. P\& I: Policy and Internet. https:// doi.org/10.1002/ poi3.183. Retrieved from https://onlinelibrary.wiley.com/doi/abs/10.1002/poi3.183

Manazir, S., \& Govind, M. (2019). Digital Democracy and India: Study of Evolution in Citizen e-Participation Framework. Retrieved from https://www.researchgate.net/publication/334921945_Digital_Democracy_and_India-_Study_of_Evolution_in_Citizen_e-Participation_Frameworks

Medaglia, R. (2007). Measuring the Diffusion of eParticipation: A Survey on Italian Local Government. Information Polity: The International Journal of Government \& Democracy in the Information Age. Vol. 12, Issue 4, p265-280.

Medaglia, R. (2012). eParticipation Research: Moving Characterization Forward (2006-2011). Government Information Quarterly, Vol. 29, Issue 3, p346-360. 
Mohiddin, A. (2002). The Challenges of e-Democracy Opportunities and Risks. Retrieved from unpan1.un.org/intradoc/groups/public/documents/cafrad/unpan007932.pdf

Mohr, J. W., \& White, H. C. (2008). How to Model an Institution. Theory and Society. P 485-512. doi: 10.1007/s11186-008-9066-0. Retrieved from https://link.springer.com/article/10.1007/s11186-0089066-0\#citeas

Paganelli, F., \& Pecchi, F. (2013). Towards a Reference Model and a Web-Based Framework for eParticipation Services Design. Information Resources Management Journal. Vol. 26, Issue 2, p1-9.

Richardson, J., \& Emerson, J. (2018). eDemocracy: An Emerging Force for Change. Stanford Social Innovation Review. Retrieved from https://ssir.org/articles/entry/edemocracy_an_emerging_force_for_change\#

Sen, A. (2005). The Argumentative Indian: Writings on Indian Culture, History and Identity. Penguin Books: UK

Singh, S. (2010). Digital Divide in India: Measurement, Determinants and Policy for Addressing the Challenges in Bridging the Digital Divide. International Journal of Innovation in the Digital Economy. 1. 124. doi: 10.4018/jide.2010040101. Retrieved from https://www.researchgate.net/publication/220136939_Digital_Divide_in_India_Measurement_Determinants_and_Policy_for_Addressing_the_Challenges_in_Bridging_the_Digital_Divide

Sharma, S. (1996). Management in New Age: Western Windows Eastern Doors. New Age International (P) Ltd: New Delhi.

Sharma, S. (2018). Women Empowerment \& Social Entrepreneurship: A LIFE Vision. Retrieved from https:// papers.ssrn.com/sol3/papers.cfm?abstract_id=3283036

Singh, B. (June 15, 2020). Assam Explores Options to Submit NRC Reverification Plea in SC. Retrieved from https:/ / economictimes.indiatimes.com/news/politics-and-nation/assam-explores-options-to-submitnrc-reverification-plea-in-sc/articleshow /76376183.cms?utm_source=contentofinterest\&utm_medium=text\&utm_campaign=cppst

Shukla, S. (September 27, 2018). Aadhar Verdict: Why Privacy Stilll Remains a Central Challenge. Retrieved from https:/ / economictimes.indiatimes.com/news/politics-and-nation/aadhaar-verdict-why-privacystill-remains-a-central-challenge/articleshow /65970934.cms?from $=\mathrm{mdr}$

The Constitution of India (1977). Retrieved from https://www.india.gov.in/sites/upload_files/npi/files/coi_part_full.pdf

UN e-Government Survey (2016). Retrieved from https:// publicadministration.un.org/egovkb/en-us/Reports/UN-E-Government-Survey-2016

Van der Graft, P., \& Svensson, J. (2006). Explaining eDemocracy Development: A Quantitative Empirical Study. Information Polity: The International Journal of Government \& Democracy in the Information Age. Vol. 11, Issue 2, p123-134. Retrieved from https://content.iospress.com/articles/information-polity/ip000092

Wong, K. L. X., \& Dobson, A. S. (2019). We're Just Data: Exploring China's Social Credit System in Relation to Digital Platform Ratings Cultures in Westernised Democracies. Global Media and China. https://doi.org/10.1177/2059436419856090. Retrieved from https://journals.sagepub.com/doi/full/10.1177/2059436419856090 


\section{About the Authors}

\section{Dr. Divya Kirti Gupta}

Divya Kirti Gupta is Associate Professor with GITAM Hyderabad Business School, GITAM (Deemed to be University), Hyderabad Campus, Hyderabad, , Telangana, INDIA. She is PhD in CSR and MBA in HR. She is Fellow, LEAD India; Ambassador (Academic \& Research Group), ISO26000 Stakeholders Global Network (ISO26000 SGN); and co-drafter of ISO26000, the International Guidance Standard on Social Responsibility of Organizations by ISO Geneva. Her research interests include Organization Behaviour, CSR, e-Democracy and eGovernance, and Management Thought.

\section{Dr. Ashish Kumar Biswas}

Dr. Ashish Kumar Biswas is Assistant Professor, Narsee Monjee Institute of Management Studies (Deemed to be University), Tarnaka, Hyderabad, Telangana, INDIA. With PhD in Economics, he is MBA in Marketing \& Finance and M.Sc. in Mathematics with 13 years of industry and academic experience and has worked with companies like Naukri.com \& Rediff.com. His areas of teaching interest include - Services Marketing, Sales and Distribution Management, Digital Marketing and Marketing Management. 